Domestic Politics and Foreign Investment:

British Development of Mexican Petroleum

Jonathan C. Brown

Department of History

University of Texas at Austin

Paper No. 87-02 
DOMESTIC POLITICS AND FOREIGN INVESTMENT: BRITISH

DEVELOPMENT OF MEXICAN PETROLEUM

\author{
Jonathan C. Brown 1 \\ The University of Teras at Austin
}

How do host country politics affect foreign business interests? This question is so complex that, while recognizing some influence, historians still concentrate on profit-making and market forces in order to analyze foreign investment, the growth of the firm, and the economic performance of lessdeveloped countries. Those concerned more with the reasons for business expansion at the source rather than at the destination seldom consider the relationship between host-country politics and foreign investment. ${ }^{2}$ others who do ponder the relationship may emphasize either the domination of local elites by foreign interests or the role of the state in promoting development. Scholarly analysis of the 'politics of modernization' most often centers on economic policies. The tendency is to assume that economic forces in and of themselves explain economic performance - whether one sees that performance in positive or pathological terms. The competition for domestic politicial power becomes a mere by-product of the profit-making (or capital accumulation) of the foreigners. 3 In other words, economic policy is mistaken for politics. The first represents the government's priorities for 
the spending of scarce public capital and the other, politics, is the struggle among power contenders to gain and maintain control of the government.

Latin Americanists of late have been intrigued by the exact relationship between domestic politics, economic policy, and development. They are finding that the half-century prior to the first world was a critical period in which foreign investment contributed to the first intensive process of economic modernization in Latin America.4 Questions remain. Eractly how much of the outcome of this development process can be attributed to the external forces, represented by foreign investment and technology, and how much by internal forces, represented by economic policy and sheer political will? Can we scholars distinguish the outcome of policy from that of politics?

This article proposes that domestic politicians struggling for power within host countries have had a more important role in shaping their modern economic environment than has been reckoned. This is not to say their control over the course of capitalist development is not ambiguous. The results of their activity (politics) often differ from their intended goals (policies), and the needs of political accomodation even in authoritarian political systems may undermine the most appropriate policies. Latin American economies in particular tend to be highly politicized. Foreign businessmen, therefore, owe much of their success and failure not only to their manipulation of production and markets but also to their individual relationships with domestic politicians.

How else can one explain the success of Sir Weetman Pearson in developing the oil business of Mexico during the regime of Porfirio Diaz? A 
British construction engineer with no prior expertise in petroleum, Sir Weetman ultimately formed the largest foreign oil company in Mexico. His success cannot be explained entirely in terms of technological knowhow, access to markets and capital, managerial competence, or entrepreneurial genius - the normal criteria used by business historians. Such an explanation actually would predict his failure, for Pearson's competitors had more of these marketplace advantages. Do Mexican economic policies account for his success? At the time, economic policy encouraged all foreign investment without discriminating as to the source. Actually, the records of Sir Weetman's company, S. Pearson \& Sons, Ltd., and British and American diplomatic correspondence suggests another hypothesis.

In part, British success in the Mexican oil industry was willed by influential Mericans engaged in a nuanced and delicate political game. They desired to utilize economic development to enhance their internal political control yet without see ming to be dominated (and thereby discredited) by American businessmen. Politicians surrounding Mexican President Porfirio Diaz encouraged all foreign oilmen but they promoted Pearson's interests above others. This political support - in combination with Sir Weetman's business acumen - enabled this British entrepreneur successfully to challenge better-placed American competitors.

\section{THE POLITICS OF DEVELOPMENT}

According to strictly business logic, American businessmen such as Henry Clay Pierce and Edward L. Doheny ought to have dominated Merico's early oil industry. After all, the United States shared 1,952 miles of border 
with Mexico. ("Poor Mexico," Porfirio Diaz supposedly remarked, "so far from God and so close to the United States.") American capital already dominated the railways, mining, and public utility industries, all of which greatly stimulated domestic consumption of oil products. When Standard Oil began exporting Pennsylvania petroleum products, Merico along with Canada and Cuba represented the nearest foreign markets. An American marketing firm with Standard Oil affiliation, the Waters-Pierce Oil Company of St. Louis was a major oil market in the lower Middle-Western states of the United States. Waters-Pierce had developed a virtual sales monopoly in Mexico as early as the 1880s. Aided by Standard Oil, Henry Clay Pierce had even established refineries in Mexico to process imported crude oil. He attempted to solidify his control of the market by purchasing interest in railways that transported and consumed oil products. 5

Doheny also was an experienced American oilman, in this case, an independent producer, before he entered Mexico. An inveterate prospector, Doheny left the New Mexican mining region in 1892 and brought in the Los Angeles oilfield. He dug his maiden oil well alongside the Los Angeles tarpits then entered the Bakersfield and Santa Maria fields. Seaching for markets, Doheny successfully introduced the petroleum-fueled steam engine to the Southern Pacific and Santa Fe railroads. A Santa Fe executive who had constructed Mexican railways brought Doheny to Merico in 1901 to investigate oil exudes along the right-of-way west of Tampico. He subsequently discovered the country's first oil field. But El Ebano yielded a modest amount of thick crude oil that neither challenged Pierce's domestic sales monopoly nor interested foreign buyers. He used it to pave Mexico's streets. ${ }^{6}$ Throughout the remainder of the first decade of the twentieth 
century, meanwhile, Doheny and his organization searched for the big oilfield in a race to provide domestic fuel oil for a Mexican railway system that ran on imported coal. Both Pierce and Doheny typify what Mira Wilkins has called the 'spillover' effect of American business expansion. ${ }^{7}$ They attempted to make profits in foreign countries almost as an extension of their domestic business activity.

Like other foreign businessmen in the country, Pierce and Doheny benefitted from the generally favorable investment climate provided by the economic policies of the long-standing Díaz regime. In 1877, Porfirio Diaz first came to power a merico immiserated by a lengthy series of civil wars, foreign invasions, losses of national territory, and political instability. Diaz benefitted from a major period of national reconstruction begun by a coalition of Liberals under the leadership of Benito Júarez. Consequently, the dominant philosophical current emphasized material progress. Positivism predicted that the progressive age, dominated by a benevolent despot, would herald the end of national weakness and religious obscurantism and would unlease the Prometean forces of wealth. Having turned over government peacefully to a successor for one term, Diaz in 1884 was reelected to a presidential post that he would not give up until forced from office in 1911. The lons period of political stability, called the Porfiriato, proved one of rapid economic development responding to increasingly massive infusions of foreign capital. By 1911 , the country had attracted an estimated 3.4 billion pesos (approximately $\$ 1.7$ billion) in direct investment and foreign loans. Mexican national income recovered to its pre-independence levels and then grew at an unprecedented annual rate of 2.3 percent between 1877 and 1910.8 Many Mexicans grew to assume that Porfirio Diaz alone had been 
responsible for reversing the nation's economic decline. It was a misconception that suited Diaz's political aspirations.

For two generations, economic prosperity served the private interests of Mexican political elites and the more narrow political interests of Porfirio Díaz himself. His was an authoritarian regime, operating under the ostensibly democratic Constitution of 1857 . As was the Mexican custom, vote fraud and state political machines dominated by local elites kept Diaz in power, while he used the nation's economic assets for his own political cause. President Diaz also took advantage of the expanding national treasury to centralize national political power. He expanded the bureaucracy, used federal patronage to placate restive state politicians throughout the nation.9 He succeeded in controlling the election and appointments of governors, congressmen, and jefes politicos (district political chiefs). Influential persons loyal to Diaz were permitted to buy public lands, organize government-protected businesses, serve as agents and attorneys of foreign interests, resell government railway and public works concessions to foreigners, speculate in real estate, form banks and brokerage houses, and engage in racketeering. 10 Porfirio Diaz enhanced his own political longevity by being indispensible to the economic prosperity on whose success of these endeavors depended. Everyone knew that foreign capital was responsible for the prosperity. His campaign propaganda even invoked the favorable opinion that foreign businessmen had of Diaz. "The capitalists and great bankers of the world will find in the reelection lof Diaz] another proof of the stability of Merican political institutions as well as of the sane judgement of the Mexican people," a Mexico City newspaper editorialized during the 1892 campaign. 11 
The president's closest supporters came to represent the foreigners in Mexico. Attorneys Pablo Macedo, Pablo Martínez del Rio, and Joaquin de Casasus, who acted as the agents of oilmen Pierce and Doheny, enjoyed access to the highest public officials in the land. After all, they were close friends of Diaz himself. 12 His permissive attitude toward influence-peddling among his supporters permitted Diaz, a former army general, to rule with a minimum of force. The army remained small, in part to prevent rise of a military competitor for power; and development of the rural police balanced the influence of the federal and state military forces. Diaz made certain that both army and police officers were indolently corrupt. Para-military thugs harassed opposition politicians; newspapers were subsidized by the government. 13 Corruption, patronage, and government contracts enhanced both Diaz's political power and the centralization of the state. They, in turn, depended upon economic expansion, which relied upon foreign investment.

While the liberals under Diaz encouraged investment, one should not conclude that foreign capitalists received a carte blanche to manipulate the Mexican economy and to pursue their own profits. Diaz's political goals had to be served as well. Part of the rationale for development had to do with national security, to be able to resist further conquest of Merican territory by the United States. 14 Given Mexico's loss of territory to its neighbor, Diaz risked politicial suicide if it appeared that the nation had become too dependent on the Americans. His administration prevented the Guggenheim interests from moving into central Merico after having consolidated much of the smelting industry in the North. The president consistently promoted British railway interests over those of the Americans, but powerful state political interests often championed American interests as a barrier to 
federal power. Northerners from Monterrey and San Luis Potosi, who in any case resented Diaz, a Southerner, in 1880 resisted the President's attempts to grant the railway concession to a British group. In the interests of turning power over peacefully to his successor, Diaz gave in, so that a defeated presidential hopeful from Monterrey, General Gerónimo Trevino, benefitted financially from selling the concession to American interests. 15 Ultimately, the central government of Diaz feared that, despite its best efforts, American 'monopolists' would gain control of Merico's railway system. His powerful finance secretary, José Yves Limantour, began purchasing railways and consolidating a national railway system under government ownership. Between 1902 and 1910, Limantour borrowed in France so that the state could buy majority stock in several separate lines. Eventually. Limantour consolidated two-thirds of Merico's steam railways into the governmentowned Ferrocarriles Nacionales de Mexico. ${ }^{16}$ The railway nationalization was as much a political as an economic measure.

The government's concern about American control of the older railway and mining sectors also produced an ambivalent attitude among Mexican officials toward American oilmen. On the one hand, the liberals had revised a number of colonial mining laws to permit private ownership of subsoil minerals. On the other, the government retained the right to regulate mining (and petroleum) industries and revoke a company's title. The legislature in 1901 placed under federal control those mineral deposits found on 'national lands, defined on vacant land, lakes, lagoons, and riverbeds. ${ }^{17}$ Merico's government found it expedient to utilize its legal and political powers to prevent American interests from controling the Merican oil industry, especially fearing the Standard Oil 'trust'. Finance Secretary Limantour 
attempted to undermine Doheny's early exploration, even to the point of forcing the resignation of a government geologist who had reported enthusiastically about Doheny's oil prospects. When this failed, Diaz simply asked Doheny never to sell his Mexican oil assets to the Standard Oil Company. 18 Ultimately, the political expediency of the Diaz politicians turned from opposing American oilmen outright, a plan that threatened to alienate all foreign investors, toward supporting competition from British interests. Mexicans were aware of the delicate connection between economics and politics in their nation. As historian Clifton Kroeber writes, "there had never been a time in Hispano-Mexican history when government and private enterprise had been thought of as separated spheres of action or of decision." 19 In other words, in Porfirian Mexico, the economy was politicized. Diaz did not wish to discredit himself either by forcing foreign capital to abandon Mexico or by permitting A merican businessmen to control the domestic economy. Such an investment environment did indeed affect the success of foreigners who, like Sir Weetman Pearson, came to do business there.

\section{AN ENGINEER OF ENERGY AND INFLUENCE}

Although Pearson had had no prior experience in the oil business, he did offer the porfiristas a number of advantages. He was a successful businessman and engineer, and he was free of connections to outside oil companies having unsavory reputations. Moreover, Sir Weetman was British and a more-polished gentleman than either Pierce or Doheny. As grandson of the founder of a modest Huddersfield construction firm, S. Pearson \& Sons, 
young Weetman declined to take training at Orford or Cambridge Universities in or der to enter his grandfather's fir ms. ${ }^{20}$ His family believed that sons should "learn their business in the business," as the saying went. At 23 years old. Pearson had become a partner. Soon he was managing the engineering anc construction of the drainage system at Ipswich and a dock at King's Lynn. Pearson moved the firm to London in 1879 and in the next decade, gained construction contracts throughout the world: docks and harbors in Egypt and Canada, rail lines in Spain, and the Hudson Tunnel in New York City. Taking over construction from less capable companies became Sir Weetman's specialty. A combination of technological innovation and sober management practices, in the meantime, had earned Pearson's company an international reputation in engineering.

Porfirio Diaz himself was responsible for bringing Sir Weetman to Mexico. In 1889, the Mexican President sent emissaries to New York in an effort to interest the famous engineer in salvaging Mexico's Grand Canal project. The American firm having the government concession to construct the Mexico City drainage system had floundered, abandoning the growing capital city to its centuries-old problem of flooding. Pearson drove a hard bargain, obtaining in negotiations with Diaz much autonomy in the construction work. Completion of the 29-mile drainage canal made Pearson the champion of Diaz. His direct link to Diaz also insulated the British engineer from having to submit to the corruption of the bureaucrats surrounding the president.

In the canal and succeeding projects, the Mexican government and the Pearson firm became partners. Mexico provided the capital and Sir Weetman, the engineering. At the time, the Diaz administration enjoyed 
budget surpluses and had an impeccable credit rating in European money markets. Mexico was one of the few countries to be able to borrow at the preferential rate of five percent. Pearson also had independent sources of capital. His company at any one time had from $\mathrm{ES}$ to $£ 10$ million worth of contracts, and London bankers and the stock market provided Pearson additional capital. ${ }^{21}$ Pearson thus was able to buy the 41-mile Veracruz-toAlvarado railway and build and own various Merican tramways and utility companies. Pearson had concentrated his interests increasingly on Mexico even before he entered the petroleum business. Diaz willingly used the British engineer as a foil to the Americans, who already dominated the smelting and railway businesses. Pearson was Diaz's choice to construct the modern harbor and dockworks at Veracruz, converting the open roadstead in front of the port into a protected harbor by means of an artificial jeddy. 22 His connections in England impressed many a Mexican. The wealthy businessman in 1895 had won a seat in the House of Commons, where he was known as "the Member for Mexico."

In the meanwhile, the Tehuantepec railway was turning out badly. The government had given the concession to another British firm in order to break the American-owned Panamanian Railroad's monopoly of transIsthmanian transport. 23 Once competed, the 190-mile line was plagued with frequently breakdowns, roadbed washouts, insufficient port capacities, and undersized railcars. Diaz in 1898 summoned Pearson to the rescue. Once again, the government provided the capital - $\$ 32.5$ million to be exact - often paying Pearson in silver bars. ("Unless special facilities had been given by the Government and subventions," Pearson wrote later, "no railways in Mexico could have been constructed."24) But the British company managed 
to retain managerial control. Once completed, the company would operate the entire complex as managing partner, sharing with the government onehalf the loss and one-third the profit. Limantour, who had been in Europe when the Tehuantepec contract was signed, criticized the liberal terms for giving the British capitalist too much autonomy. Diaz supported Pearson. Nevertheless, a second contract renegotiated between Pearson and the government in 1902 tightened the restrictions. The contract prevented Pearson from selling his Tehuantepec interests to the Americans, although he could sell to other foreigners. ${ }^{25}$

By now, Pearson had assembled an experienced staff in Merico. J. B. Body had served as assistant manager of the Grand Canal and then was chief of the Veracruz harbor construction. Since 1889 , he had come to speak Spanish fluently, often translating at meetings between Diaz and Pearson. Body took charge of a Tehuantepec project that really was more than refurbishing a railroad. S. Pearson \& Sons was to build a completely new transportation complex. Supervising the work of between 2,000 and 5,00 workers recruited from the Highlands, Body constructed a new roadbed, a flood control system, extensive bridging, breakwaters and docks at the Pacific terminus of Salina Cruz, and dredging and dockwork at the Gulf terminus of Coatzacoalcos. The latter river port was rechristened as Puerto Mérico.26 When he inaugurated the Tehuantepec complex with a train-ride in 1907, Diaz was effusive in his praise:27

Portions of the Isthmus have been literally remade. Flourishing new towns with pretty and comfortable houses and contented inhabitants owe their existence to the energy and courage of Sir Weetman Pearson, whose name will endure and be held in honour in this historic region of Mexico, long after the rails on which our party has glided so smoothly have become eroded by age. 
Pearson owed his success in Mexico to his world-wide business experience, his access to the engineering technology of the day, to his financial resources among London bankers, and to the capital and patronage of the Diaz government. These factors enabled S. Pearson \& Sons, engineers and contractors, to become oilmen as well. All except one: Diaz provided no capital for oil projects. Yet his government helped Pearson in other tangible ways.

\section{PEARSON ENTERS THE OIL BUSINESS}

Pearson's decision to exploit Mexico's oil resources, although it eventually proved a sound one from the standpoint of profits, had come to him in a round-about fashion. In 1901, he was traveling by train between Merico and New York. Pearson spent the night at Laredo, Texas, just weeks after Anthony J. Lucas's spectacular oil strike at Spindletop. Everyone on the Texas Gulf Coast seemed to be in the grip of 'oil fever.' Pearson made inquiries about this new oil business and learned that prospectors had been attracted to Spindletop by the very same kinds of tar pools that Body had found along the route of the Tehuantepec Railway. Pearson immediately wired Body to "secure option not only on oil land, but all land for miles round" in the Isthmus of Tehuantepec. Pearson added, "move sharply, and be sure that we are dealing with principals."28 By the end of 1901, he had men exploring the Isthmus and in Tabasco. They began immediately to buy and lease land on the Isthmus, and Pearson again hired outside expertise in the person of the very Anthony Lucas who had brought in the Spindletop field. 
General Manager Body was gaining an education in the oil business in the best Pearson tradition, while on the job. He negotiated for the purchase of numerous large estates in the Isthmus, rejecting some after a visual look for prospects and buying others for as little as 6,000 pesos (approximately $\$ 3,000$ ). He took out leases with important elite families such as that of Rubio Romero, in-laws of President Diaz. Mrs. Diaz, in fact, became a leasor on contracts that provided for royalties of two to five centavos per barrel ( 42 gallons) of crude produced at San Cristóbal. By 1903, his Merican managers were moving drilling equipment from the Vera Cruz docks to the Isthmanian oil properties. 29

At the same time that work progressed on the trans-Isthmanian rail and port project, Pearson's agents also were assembling and putting men to work on the Mexican oil properties. Body hired Thomas J. Ryder away from the Waters-Pierce Oil Company and then engaged some of the same drillers who had worked for Doheny at El Ebano. The early work on the Isthmus did not prove to be promising. Many wells blew out gas, mud, and water but little in the way of crude petroleum. The first Tabasco wells produced in such insufficient quantities that the Pearson managers used it in its crude state as fuel oil. 30 Yet the expectations remained high. Those wells that did produce, yielded a high grade of crude suitable for fuel oil, lubricants, illuminants, and naphtha. At first, Body and Pearson entertained greater expectations than, in fact, the foreign interests ever were to realize in Southern Veracruz, Tabasco, and Campeche, where the Pearson firm owned 600,000 acres and leased an addition 300,000 acres of oil lands. ${ }^{31}$ Despite Pearson's financial ability to hire the best managerial talent, drilling expertise, and legal and political minds available in Mexico, his company was 
incapable of opening up the area that in the mid-1970s would become the prolific Reforma oilfields. They could not drill deep enough. The cable tools of 1905 seldom penetrated 3,000 feet below the surface. Drillers for Petroleos Mexicanos (Pemex, the national oil company) in the 1970s perforated on- and off-shore from 15,000 to 30,000 feet. 32 Had they lived long enough, Pearson and Body might have been gratified that their initial optimism in Southeastern Merico was borne out. Even though the geology confounded him, Pearson had political contacts that gave him enormous confidence.

Sir Weetman Pearson had come to practice a sort of business diplomacy meant to create a favorable political climate for his enterprises. The British engineer solidified his friendships in Mexico through favors and gifts. When he visited Mexico, Pearson brought valuable European objects d'art for Secretary Limantour's home; he lent money to Mexican friends; he entertained Porfirio Diaz, Jr. when the president's son toured Europe; and Body made his home in Veracruz available to traveling notables like the Rubio Romero.33 Lady Annie Cass Pearson established a well-appointed home in a colonial mansion that once had been the British legation, giving gala parties there for Mexican society. The Pearsons donated \& 100,000 to found the Cowdray Hospital in the city. Pearson had found it expedient to "lean over backwards" to favor the Mexicans in all his dealings with them. 34 To counter a bad press in some Mexican newspapers, Body used company funds to advertise, to print their views on certain issues, and to gain the 'cooperation' of newsmen.35 Body also was careful to apprise President Diaz personally of all his company's activities. When a flare-up of nationalism in 1905 motivated the Academy of Jurisprudence to criticize a proposed oil 
law as being too liberal and unrestrictive, President Diaz himself calmed Body. The president had assured him, Body reported, that the Pearson group could "devote a lot more time to the direct work of the fields, instead of spending so much time and worry on legal matters and titles to protect ourselves in and around our fields of exploitation."36 While Diaz remained in charge, the British and other oilmen were able to concentrate on business.

Pearson's close relations with members of the Diaz regime paid a large dividend in 1906, when the engineering company received the biggest government oil concession of all, a 50-year contract covering all national land, lakes, and lagoons in the state of Veracruz. The company obligated itself to deposit 40,000 pesos with the government as security, maintain a refinery (the one at Minatitlán), spend 800,000 pesos in exploration within seven years, file reports with the government ministries, and permit government inspections. The national government was to receive a royalty of seven percent of all production. Veracruz state obtained a royalty of three percent. In return, the government granted the company duty-free import of machinery, free export of oil found on subject lands, tax exemptions, a pipeline concession, and the right to sell. The government added a telling caveat: the oil company exploiting the concession was to be incorporated in Merico, not abroad 37 None of the concessionary lands were to yield any major oil discovery, yet the government generosity provides testimony to the interest of the Diaz government in the success of the Pearson oil group.

Such influence and government support contained its own limitations and dangers to the businessman. Secretary of Finance Limantour, most powerful of Diaz' ministers, proved a difficult man for the Pearson interests 
helped build the Minatitlan Refinery. 11 Nert came the problem of markets for refined oil. Pearson was confident he could undersell Pierce's imported product on Mexico's domestic market. Although he did not expect to sell to U.S. markets, Pearson acquired Bowrings \& Co., a petroleum distributor in Great Britain. In 1908, a fire shut down the Minatitlán plant, providing Pearson the opportunity correct certain processes and improve the quality of the product. 42 Pearson planned to enlarge the refinery to a capacity of $40,000 \mathrm{~b} / \mathrm{d}$, enough to supply fuel oil to the Mexican railways and also to export to Great Britain.

Yet up to 1908, the British businessman was still losing money. Pearson had sunk $\mathrm{E} 5$ million of his own capital into the oil venture, as his operating expenditures for the oilfields and the refinery alone were amounting to $£ 100,000$ sterling per year. Construction of the refinery had been expensive. By 1907, Body already had overseen the expenditure of 630,000 pesos for American machinery, dock and brickworks, machine shops, power station, warehouse, pipelines, staff housing, and a hospital. Optimistically, Body planned on making at least $£ 5,000$ a month selling fuel oil to the railways but admitted that such sales were not yet possible. 43 The Diaz government did not become his financial partner as it had for the engineering projects. If he was going to stay in the petroleum business, Pearson had to make some sales and make them soon.

Of course, the Pearson company could neither refine nor sell until it secured a supply of crude oil! By 1908 , when refinery expansion had been completed, a pipeline connected the facility to Pearson's newly-constructed oil terminal at Puerto Mérico, alias Coatzalcoalcos. Here his refinery took on crude oil supplies via steam tankers and pipeline. The paucity of Merican oil 
production motivated the Pearson group to purchase 400,000 barrels of crude oil from Texas. 44 Thus far, Pearson was not very different from Waters-Pierce - he was selling imported American crude which he refined in Mexico. But Pearson did have more political friends in the Diaz regime than any of his competitors, an advantage in Mexico's politicized investment environment.

\section{A REFINER FINDS OIL - FINALLY}

In Merico, the oil companies developed differently than had the big petroleum firms in the United States. Standard Oil began as a refinery group that integrated forward and backward into sales, transport, and production. Others like Gulf and Teraco had begun as producers who became integrated by acquiring refining and sales. 45 In a process of simultaneous integration, however, both Pearson and Doheny from the beginning attempted to form integrated oil firms in Merico. Doheny set up a refinery at his El Ebano oilfield and developed his own sales network that, however, was limited by having only heavy crude. Unable to challenge Waters-Pierce monopoly on sales of lighter oil products such as kerosene and lubricants, Doheny's company used El Ebano's heavy oil to pave the streets of Merico's larger cities and to fuel some of the nation's steam locomotives. 46 In similar fashion, Pearson built a refinery and acquired a transport and sales organization at the same time that he was trying to develop production. Because part of his sales organization, Bowrings, was in England, perhaps the fledgling foreign oil company in Merico might qualify as a multinational corporation. Both Doheny and Pearson were impelled toward integration by 
the same motives identified by Alfred Chandler as motivating United States firms to begin foreign operations. Pearson and Doheny wished "to reduce costs by exploiting the economies of throughput" and "to assure a constant flow of materials into processing and manufacturing plants on a precise schedule and to precise specifications." 47 Competition motivated the economies of throughput.

Waters-Pierce did not participate in simultaneous integration at all. Its long-term contract committed Waters-Pierce to purchase petroleum products only from other Standard Oil-affiliated companies. Although the parent firm permitted Pierce to have refineries in Mexico in order to avoid import tariffs on refined products, Waters-Pierce was not a refining company. It had no refineries in its larger Southwestern U.S. markets. Therefore, Waters-Pierce was destined to lose its monopoly sales position in Mexico to the two fully integrated companies belonging to Doheny and Pearson. For the moment, the difficulty of discovering a supply of domestic Merican crude oil proved a bottleneck to the simultaneous integration within both organizations.

Sir Weetman's solution was to buy crude oil. Another British oilman in Mexico. Percy Furber had found a modest deposit of high-grade crude oil at a wilderness location about 75 miles southwest of Tuxpan, but he lacked the financial and technological backing that Doheny and Pearson were able to muster. His small oilfield was named Furbero. Pearson's group agreed to purchase from 2,000 to 6,000 barrels per day (b/d) of Furbero crude, and crews began to build a narrow gauge railway and a 6 -inch pipeline to Tuxpan. 48 But by 1910 , the Furbero oilfield was producing not more than $600 \mathrm{~b} / \mathrm{d}$. Some in Pearson's organization suspected that Furber might have 
been telling his workers to hold back production. 49 Clearly, buying crude oil from so unreliable a source provided no solution to the production needs of Pearson, the refiner and marketer.

Because Mexico's oil industry, like its general economy, was linked to that of the United States, Pearson did not have to rely exclusively on Furber for supplies of fuel oil. Low prices, especially on the Gulf Coast, encouraged Pearson to buy Texas crude, refine it at Minatitlán and sell it throughout Merico. In a way, Mexico's nascent oil industry benefitted from low U.S. oil prices in the first decade of the twentieth century. Pearson was able to break the Wasters-Pierce sales monopoly with cheap imported oil before the even-cheaper Mexican production had come in.

Meanwhile, both Doheny and Pearson were directing their attention to the Faja de Oro, the legendery Golden Lane that lies along the coastal plain west of Tuxpan. Pearson's agents were in the Faja de Oro as early as 1906, competing with Doheny's agents over the purchase and leasing of potential oil properties. The unstructured nature of land titles in an area of only limited agricultural development caused some problems. Pearson and Doheny interests moved into what would be a prolonged conflict over the estate of the widow Gorochtegui. The case illustrates that the oil business sometimes knew no nationality, for Doheny's agent in Tuxpan was British and Pearson's was a German immigrant from Chicago. 50 Ultimately, the Pearson agent arranged leases at Tierra Amarilla with a second influencial family in Tuxpan, the Peláez, retaining the eldest son as one of his Merican legal consultants. Manuel, the second son of the Peláez clan, was to involve the oil companies in the Revolution when, from 1914 to 1920 , he made 
himself the local caudillo of the Faja de Oro.51 The foreign interests were as much implicated in local as in national politics.

Pearson's move into the Golden Lane to challenge Doheny proved a momentous setback and a spur - all at the same time. Pearson had drilling crews who were putting down wildcat wells at the Haciendas San Diego and Dos Bocas west of Tuxpan. In the Spring of 1908, a 2,000-b/d well that came in at San Diego was Pearson's first oil production outside the Isthmanian region. In July, a crew of Americans using cable drilling tools had already reached a depth of 1800 feet on a second exploratory well, named Dos Bocas. The well blew in and immmediately the spouting column of oil and gas caught fire. The American consul at Tampico described the conflagration at Dos Bocas: 32

The heat was so intense that it is impossible to go nearer than several hundred reet. Considering the great quantity of oil coming out, there is little gas. The internal pressure is tremendous. The height at which the oil first ignites is forty feet. The steady height of the column of oil is 850 feet while gusts of wind are constantly deflecting the main flame and portions of the burning air to an immense height, of tentimes erceeding fourteen hundred feet. The flame inself is visible at thirty miles distance while the light, under favorable atmospheric conditions, can be seen two hundred miles.

The giant torch burned so hot that workers were unable to get near enough to start capping the enormous hole through which the crude oil continued to blow at the rate of $100,000 \mathrm{~b} / \mathrm{d} .53$ Dos Bocas burned like this for two months, leaving the well a gapping, bubbling crater of salt water and sulphur gas. But the Dos Bocas blowout and the San Diego production made everyone in the Pearson organization confident that it soon would discover a prolific oiffield. It showed that expanded production was imminent. 


\section{THE GREAT MEXICO OIL WAR}

Confident of future discoveries and bolstered by his own modest production and by what he purchased from Furbero and Teras, Pearson decided to move on the Waters-Pierce sales monopoly. His political connections proved useful. In fact, much of Pearson's negotiations with Pierce had been proceeding simultaneously to his crude oil purchases and exploratory programs. Sir Weetman approached Henry Clay Pierce at the end of November 1907. The British engineer speculated that Pierce's profit margins - calculated at 100 pesos (\$50) per ton - were too high. He proposed that together the two oilmen reduce those margins closer to 25 pesos per ton. What Pearson suggested was a combination between the two companies that would keep out other competitors - in other words, that Pierce turn his monopoly into a cartel.54 The British capitalist traveled to New York to meet with Pierce. He proposed that the British company provide Pierce with Mexican crude oil (a proposal based on expected production) and receive one-third of Pierce's total profits. Waters-Pierce was to serve as Pearson's exclusive marketer in Mexico, while Pearson became the sole producer for the domestic market.55 Finance Secretary Limantour agreed to the proposal beforehand, as long as Mexican oil prices did not rise.

However, the two oilmen came to a deadlock over fuel oil, which promised to be the largest Mexican market in the near future. Pearson wanted to include only traditional Waters-Pierce products, like lubricants and kerosene, in the cartel agreement. But Pierce, who never had had any 
fuel oil sales in Merico, wanted to make fuel part of the deal. As the British learned later, Henry Clay Pierce was at the same moment negotiating to buy Doheny's surplus production at El Ebano.56 Pierce's flexibility was extremely limited. Any breach of his agreement with Standard Oil over Merico exposed Pierce's dependence on Standard Oil's supply of petroleum products in the more lucrative U.S. market, where Wasters-Pierce had no refineries. Beside, Pierce and Standard president, John D. Archbold, were not on speaking terms. At the time, a round of court battles in Texas was distracting Pierce, and, it was rumored, he was 'racked with illness.' Pearson at any rate felt that Pierce was delaying for time. He ordered Body to began buying railroad tank cars and distribution depots in the ten largest Merican market centers. Offering petroleum products to Merican merchants at a 20 percent discount, Body was to enter Merico's retail trade. 57 At the same time, negotiations continued. Believing that Waters-Pierce and Standard Oil were nearing a breech, Pearson established contact with the directors at 26 Broadway. Pearson did not desire Pierce to "use us as lal pawn" in settling his differences with Standard Oil. Archbold informed Pearson that, because it was facing its own court litigation, Standard Oil momentarily was unable to do anything in Merico. 58 With Doheny momentarily stuck in his heavy oil, and Standard Oil preoccupied by court proceedings, the Pearson and WatersPierce groups were left to struggle over the Mexican market.

Negotiations broke down in June 1908 , signaling the beginning of the great Mexican oil war.' Pearson consulted with President Diaz and Secretary of Finance Limantour, both of whom had distrusted the negotiations between Pearson and Henry Clay Pierce. Limantour especially feared that Sir Weetman's combination with Pierce would only encourage Standard Oil to 
buy them both out. For some time, Pearson had been planning to form a Mexican company. "After full consideration I have decided to form a Mexican Company to take over all our oil interests north of Vera Cruz." Sir Weetman wrote. "This Company will trade only in Merico and I want Merican capital to be interested. Then the Oil interests at San Cristobal and the Refinery would remain ours and be devoted to export business."59 A national company met the political goals of the Diaz regime, which all along had been urging Pearson to incorporate in Mexico

By April of 1909, therefore, Pearson had completed the formation of the Companía Mexicana de Petroleo 'El Aguila.' Although the Mexican company absorbed all of the oil properties of S. Pearson \& Son, Ltd., the British engineering firm, the parent firm remained the primary stockholder. Going public facilitied the expansion of stock value to $£ 2,550,000$. Few Mexicans bought El Aguila stock, yet several prominent members of the 'ruling class' served as directors. Guillermo Landa y Escandón, governor of the Federal District, was president. On the board were Enrique Creel, Governor of Chihuahua and former Mexican Ambassador to the United States; Pablo Macedo, board chairman of the National Railways of Mexico, Fernando Pimentel y Fagoaga, President of the Central Bank; and Col. Porfirio Diaz, Jr., the president's son. 60 All of these men were close associates of Finance Minister Limantour and formed the inner circle cientificos (literally, the educated ones) that surrounded Porfirio Diaz. Creation of a 'Merican' company at least mollified this clique of politicians.

The organization of El Aguila provided Pearson the political resources to attack the Waters-Pierce monopoly. The administration already had raised the cost of oil products traditionally imported by Waters-Pierce by 
increasing import tariffs. The government stated it intended to impart "a moderate degree of protection to certain Mexican industries which are capable of easy and vigorous development."61 Friends in high places also secured for El Aguila a National Railways contract to supply one-third of its lubricating oils. Heretorore, Waters-Pierce had been the sole supplier. 62 From this point onward, Henry Clay Pierce removed his gloves and began a publicity campaign to discredit the political connections of El Aguila. Pearson would come to be tied inextricably to the soon-discredited Diaz regime. The first press salvos of Waters-Pierce were defensive: 63

We have created a new industry in Merico and for Merico. Over 90 per cent. of the employees engaged in this work are Mexicans. We have taught them a new trade, and built refineries in which they can follow it. We believe that these acts constitute as just grounds for our claim to be in essence a Mexican concern as would the assumption of a Mexican name that would simply be a veil to thinly conceal foreign ownership.

Other salvos were deliberately offensive. Bureaucrats in Limantour's Treasury Ministry were not amused when they read news stories suggesting that $W$ aters-Pierce alone had been responsible for the nation's budget surpluses even before the government ungratefully raised import duties. 64 Moreover, rumors spread through the American community in Merico. They suggested that Diaz was a silent partner in Pearson's enterprises and that the rise in import duties had been a 'conspiracy. 65 In a way, Waters-Pierce contributed to the rising criticism in Mexico that was undermining the Diaz regime.

At the time that news of the Dos Bocas blowout sent shock waves throughout Mexico, in July of 1908 , Pearson went public with his marketing plans. His company announced that it now had 50 forty-ton tank cars to 
carry fuel oil from its $6,000 \mathrm{~b} / \mathrm{d}$-refinery at Minatitlán to bulk storage installations in 10 Mexican states. Newspapers carried the information that the government again was considering raising the duties on petroleum imports. Reports stated that the new 'Merican' company, El Aguila, by cutting prices 20 percent, would break 'Standard Oil's control of Mexico' once and for all. "The domestic consumer of Mexico will at once enjoy the luxury of cheaper oil than they have even know before. 66 Within months, the war became more vicious. Thomas J. Ryder, the former Waters-Pierce agent and now chief of Pearson's oil department, began to expand Pearson's retail distribution throughout Mexico by hiring other experienced Pierce agents. By the end of October 1908, Pearson had 72 distribution agencies in Mexico. 67

Mexican oil prices, which once had been four-times greater than U.S. retail prices, begin to tumble beyond the initial 20 -percent cut as Pearson's retailing organization expanded. Kerosene fell from thirteen to seven centavos, and gasoline fell from 35 to eleven centavos. ${ }^{68}$ The newlynationalized Mexican railways in November concluded a contract in which Pearson was to supply fuel oil over a seven-year perod for about 920 kilometers of line. Pearson agreed to build tank storage depots in the train yards at Veracruz, Orizaba, and Puebla. Plans also went forward to construct an oil terminal at the Veracruz port.69 At this point, the president of Waters-Pierce and son of the board chairman, Clay Arthur Pierce, traveled to Mexico in order to shore up the American company's declining market share. His statements to the Mexico City press, however, were somewhat inopportune. "Consumers of [Waters-Pierce] materials get the product of the Pennsylvania fields, which is the very finest oil found anywhere," Clay 
Arthur Pierce told reporters. But he refused to respond to their queries about when his company would begin to produce products from Mexican as opposed to Pennsylvanian crude. ${ }^{70}$

The 'great oil war' in Mexico, because it lowered prices, tended simultaneously to widen the consumption of petroleum products throughout the country. El Aguila agents noted that nationwide sales of illuminating oil and naphtha had risen from 9 million gallons per month in 1906 to 12 million gallons in 1909. In fact, Pierce's volume sales and its imports had not decreased. But the oil war did diminish the net sales receipts at the same moment that it eroded the market domination of Waters-Pierce. ${ }^{71}$ Pearson's assault on the American oil interests, aided by the government, culminated in the capture of half of Merico's growing oil sales.

Next came the breakthrough in production. Having failed to tame the Dos Bocas blowout, Pearson in 1909 decided to hire C. Willard Hayes, chief of the U.S. Geological Survey. As a high-paid consultant but without giving up his position at the Survey, Hayes was to engage field geologists and inspect their exploratory work once a year. ${ }^{72}$ He brought in a bright, young geology student from the University of Oklahoma, C. Everitt DeGolyer. Together with two other American field geologists. DeGolyer traveled to the El Aguila properties west of Tuxpan. They chose the drilling sites for four exploratory wells at an hacienda named Potrero del Llano, $\mathbf{4 0}$ miles northwest of Tuxpan. DeGolyer later recalled that the first well at Potrero del Llano had "drilled itself in" while the crew was having dinner. The discovery well, Potrero del Llano No. 1, "flowed by heads and made three or four hundred barrels a day. There was no difficulty in stopping the free flow of a well of that size, just a matter of closing a valve. ${ }^{.73}$ With his geologists and drilling crews working 
on addition prospects, Pearson felt assured he would soon have enough domestic crude so that he would be able to cancel the purchases of Teras crude. He wanted a big well that would not stop with the mere turn of a valve.

DeGolyer located the fourth well-site at Potrero del Llano. The drillers stopped their work after having penetrated 1911 feet into the Tamasopa limestone, Potrero No. 4 came on its own. A black plume of crude petroleum rose 250 feet into the air with a deafening roar and commenced to lay a coat of oil over all the vegetation - and human and animal life - for a radius of a mile around the well. That the boilers purposely had been placed some distance from the drilling platform prevented Potrero del Llano No. 4 from becoming another Dos Bocas-like conflagration.

The fury of Potrero No. 4 challenged experienced British and American oilmen to devise additional technological solutions to problems peculiar to Mexican production. Accompanied by a large quantity of gas, the oil spewed out of the well at the rate of $100,000 \mathrm{~b} / \mathrm{d}$. The pressure heated the oil to $\mathrm{a}$ temperature of $147^{\circ} \mathrm{F}^{74}$ Crude petroleum flowed into the Tuxpan River and out onto the beaches along the Gulf Coast of Veracruz. Engineers experienced in Texas and Baku devised an elaborate valve dubbed the "Bell Nipple" after a design that an American driller had seen used on much smaller Texas gushers. Eventually, they winched the bell nipple upright and over the blasting spout of crude. Best of all for El Aguila, the crude oil at Number 4 had an A.P.I. rating of $21^{\circ}$ gravity. Unlike the heavy crude produced at Doheny's El Ebano in the north, the wells in the Faja de Oro contained large increments fuel oil, kerosene, and gasoline - the valuable products of oil. Cowdray's men in Mexico had harnessed a well that, once it 
was pinched back, produced at the rate of $30,000 \mathrm{~b} / \mathrm{d} .75$ Many oilfields produced less than Potrero del Llano No. 4 did alone!

Finding itself suddenly awash in oil production, the company now had to move quickly toward simultaneous integration. El Aguila lacked adequate transport and refining. J. B. Body devised a floating loading dock in the shallows before the river port of Tuxpan, so that Gulf tankers could take on crude oil approximately one-half mile from shore. ${ }^{76}$ The drilling crew at Potrero del Llano had slowed down while others built a pipeline that carried the modest production of Tierra Amarillo and San Diego to the Tamiahua lagoon. From there, barges ferried the crude oil over to El Aguila's new refinery at Tampico. Work then commenced on the pipeline from Portrero directly to the deep water port of Tampico. Potrero del Llano crude also was shipped to Puerto Mérico, and pumped to the Minatitlán refinery. 77 Lord Cowdray, as Pearson was to be know after his elevation to the peerage in July 1910, expanded the new Anglo-Mexican Petroleum Company (created from the old Bowrings sales fir $m$ ) into an 800-person organization distributing Mexican oil throughout Great Britain and the Continent. ${ }^{78} \mathrm{El}$ Aguila's discovery successfully countered those of the experienced American oil prospector, Edward L. Doheny. His new Golden Lane producing company, Huasteca (incorporated in the U.S. despite its name), had discovered prolific wells at Casiano. Huasteca also build pipelines and a refinery at Tampico, acquired ocean tankers, and created a refining and marketing organization in the United States. ${ }^{79}$ However, Doheny's company expanded very slowly into the Mexican marketplace, because it was already captured by El Aguila.

Now Mexico became a petroleum exporter. The prolific wells of El Aguila and Huasteca had made Merican oil competitive on the U.S. market, 
depressing world oil prices in the process. Steam tankers began to arrive from the United States. Both Doheny and Lord Cowdray laid plans to build their own fleets to carry Mexican oil to the Gulf and Atlantic states, Canada, Europe, and Latin America. Mexican production burgeoned from a 3.6 million barrels in 1910 to 12.6 million in 1911. (See Table.) The foreign oilmen had effected the conversion of Mexico from a net importer to an exporter of hydrocarbons in May 1911. Ironically, this was the very month that President Diaz and many Mexican board members of El Aguila went into European erile.

In the final analysis, Diaz and his older political supporters discovered just how ambiguous was their power to control the forces of modern capitalism. The president always had reminded his minions that he alone had the power to keep the Americans at bay. ${ }^{80}$ That was part of his mystique. Yet the evidence of foreign penetration into Mexico became increasingly difficult to ignore. In the cities, foreign shopkeepers and products abounded. An estimated 20,000 Americans, and 15,000 Englishmen, among other foreigners, managed the more successful enterprises, and alien workers commanded the skilled positions and highest salaries. During the financial crisis of 1906-1907, graffiti throughout the country proclaimed 'Merico for the Mericans,' a sentiment that appealed to the native proletariat and bourgeoisie alike. 81 Diaz could not easily repudiate the foreign capital on which he had so carefully built and financed his political machine. As his authoritarian regime matured, he was unable or perhaps unwilling - to reduce the concentration of economic assets into the hands of a narrow group of cientificos. Excessive privilege and wealth rankled those omitted from the inner circle. ${ }^{82}$ on the one hand, he had 
drawn the foreign interests into the Merican political game; on the other, the appearance of his subservience to foreigners like Lord Cowdray ultimately contributed to his downfall.

This article contends that the politicians surrounding President Porfirio Diaz bore direct responsibility for the success of British interests in the nascent Mexican oil industry. In the first place, Merican liberals had adopted a commitment to modernizing and strengthening the nation by encouraging the entry of foreign capital. Diaz himself supported economic expansion. It provided him the resources to enhance federal powers and to assure his own continuance in office. Yet the Merican politicians, for historic reasons, could not appear to allow the economy to be dominated by American interests. For this reason, the administration showed considerable favoritism toward the work of European businessmen. Diaz himself invited Sir Weetman Pearsun to Mexico in order to develop projects that Americans had abandoned or those which Diaz did not want Americans to succeed. Deliberately contributing to Pearson's engineering and business triumphs in the country, the government agreed to liberal contracts and financially underwrote many of his projects. Although it declined to offer capital for Pearson's oil projects, the government did provide other kinds of favoritism. Tariff protection, access to political insiders, tax benefits, generous government oil concessions, and purchases of El Aguila fuel by the national railways helped Pearson maintain his business momentum for an entire decade while he competed against more experienced American oilmen in Merico. Pearson's astute creation of managerial organization and development of technological expertise accomplished the rest. 
The Pearson case quite clearly indicates that Mexican politicians contributed significantly to the manner in which capitalism developed within their own country. Porfirio Diaz's reputation has been much diminished by the Revolution. Yet, his economic policies up to 1911, the incipient age of the Mexican oil industry, had an enduring impact. El Aguila survived to become the largest foreign oil concern in the country. In 1919, Lord Cowdray eventually sold his growing Mexican oil interests to a non-American company, the Royal Dutch/Shell group. Waters-Pierce became separated from Jersey Standard in the 1911 Dissolution case. Its presence in Mexico thereafter remained but a faint reminder of its once-dominant role in developing the Mexican market for petroleum products. While very large indeed, Doheny's Merican company never equalled El Aguila's volume. Although the Standard Oil Company of Indiana and then Standard Oil Company (New Jersey) eventually acquired Doheny's assets in 1925 and 1932 respectively, no single A merican oil firm ever surpassed the production and domestic sales of El Aguila. Furthermore, the dichotomous ownership of the oil industry weakened the foreign oilmen's resistance to the economic nationalism generated by the Mexican Revolution. Successive Mexican administrations after 1912 increased the taxation and worked to erode the property rights of the foreign oil companies. 83 El Aguila, still directed into the 1930 s by many of Pearson's old managers, always was more willing than the American-owned companies to make concessions toward the government and to Mexican labor unions, when they became a factor after 1917. In a way, the legacy of Porfirio Diaz continued to influence company-government relations right up to the Mexican expropriation of the foreign-owned petroleum industry in 1938. The operations of foreign 
enterprise in Mexico cannot be explained entirely in terms of economic forces.

11 would like to thank the American Council of Learned Scholars and the Graduate Research Institute of the University of Texas, which provided me grants to undertake research in London in 1982 and in Washington in 1984.

2Prominent in the literature of foreign investment are Mira Wilkins, The Emergence of Multinational Enterprise: American Business Abroad from the Colonial Era to 19/4(Cambridge, Mass., 1981); Charles P. Kindleberger, American Business Abroad: Sir Lectures on Direct Investment (New Haven, 1969); and Stephen Hymer, The International Operations of National Firms: A Study of Direct Foreign Investment (Cambridge, Mass., 1976).

3 For works critical of foreign investment, see N. Lenin, "Imperialism, the Last Stage of Capitalism" in /mperialism: The State and Revolution (New York, 1926), 6-114; Immanuel Wallerstein, "The Rise and Future Demise of the World Capitalist System: Concepts for Comparative Analysis," Comparative Studies in Society and History, v. 16 (1974), 387-415; Arghiri Emmanuel, Unequal Exchange: A Study of the Imperialism of Trade, translated from the French by Brian Pearce (London, 1972); and Nora 
Hamilton, The Limits of State Autonomy: Post-Revolutionary Merico (Princeton, 1982). For a review of the literature, see D. K. Fieldhouse, "The Multinational: A Critique of a Concept," in Multinational Enterprise in Historical Perspective, edited by Alice Teichova, Maurice Lévy-Leboyer, and Helga Nussbaum (Cambridge, 1986), 9-29. Other scholars acknowledge the positive role of politics in the developmental process. See especially Wilkins, The Emergence of Multinational Enterprise, 101; and W. W. Rostow, The Stages of Economic Growth, 2nd ed. (Cambridge, 1971), 26; and Rostow, How It Al/ Began: Origins of the Modern Bconomy(New York, 1975), chapter 2.

4Representative works include Laura Randall, A Comparative Economic History of Latin America, 1500-1914,3 vols. (Ann Arbor, 1978); D. C. M. Platt, ed., Business Imperialism, 1840-1930: An Inquiry Based on Brjtish Experience in Latin America (Oxford, 1977); and Marshall C. Eakin, "Business Imperialism and British Enterprise in Brazil: The St. John d'el Rey Mining Company, Limited, 1830-1960," Hispanic American Historical Review, 66:4 (1986), 697-742. Also see several articles appearing in this journal such as Mark Wasserman, "Enrique C. Creel: Business and Politics in Mexico, 1880-1930," Business ffistory Review, 59:4 (1985), 645-622; and Christopher Armstrong and H. V. Nelles, "A Curious Capital Flow: Canadian Investment in Mexico, 1902-1910," BHR, 58:2 (1984), 178-203.

Spierce served as chairman of the board of the Mexican Central Railway that connected Merico City, San Luis Potosi, Monterrey, Tampico, and Nuevo Laredo. See the references to the Waters-Pierce Oil Company in Ralph W. Hidy and Muriel E. Hidy, Pioneering in Big Business, 18821911: History of Standard Oil Company (New Jersey)(New York. 
1955). Also see the testimony of Robert H. McNall in United States Supreme Court, Transcript of Record: The Waters-Pierce Oil Company vs. The State of Texas, October term, 1908, no. 356 (Washington, D. C., 1909); and of H. C. Pierce in United States Supreme Court, Transcript of Record, Standard Oil Company, et. al., vs the United States, October term, 1909, 221 U.S. 1 (Washington, D. C., 1910).

6For Doheny's early career, see Ward Ritchie, The Dohenys of Los Angeles (Los Angeles, 1974); and Clarence W. Barron, The Mexican Problem (Boston, 1917); and Doheny's testimony in United States Congress, Senate, Committee on Foreign Relations Ihereafter, Senate Committee on Foreign Relations], Revolutions in Meyico: Hearing Before a Subcommittee of the Committee on Foreign Relations. 62th Congress, 2nd session (Washington, D. C. 1913).

${ }^{7}$ Wilkins, The Emergence of Multinational Enterprise, 113-48.

${ }^{8}$ Leopoldo Zea, Apogeo y decadencia del positivism en Mérico (Mexico City, 1944), 42; Daniel Cosío Villegas, editor, Historia moderna de Mérico, 9 vols, (Mexico City, 1955-1972), vol. 5, El Porfiato: La vida economica, pt. 2, 1154; and John Coatsworth, "Obstacles to Economic Growth in Nineteenth Century Mexico," American Historical Review, 83:1 (February 1978), 800-100.

Fof the importance of patronage, Laurens Ballard Perry writes: "One of the implications of the relationship between the caudillo en jefe [Diaz] and the local caudillos who supported him was that the caudillo en jefe was subject to the recommendations of the local caudillos to name partisans of the latter to positions as they arose." Perry, Juarez and Diaz: Machine Poljtics in Merico (DeKalb, 1978), 207. In the banking enterprises of the Terrazas and Creel families of Chihuahua, Mark Wassserman provides an apt 
illustration of "the conjunction of business and politics." Wasserman, "Enrique C. Creel," 650-651.

10Francisco Bulnes, El verdadero Diaz y la Revolución (Mexico, 1920); Carleton Beals, Porfirjo Diaz: Dictator of Mexico(Philadelphia, 1932); and Alan Knight, The Mexican Revolution, 2 vols. (Cambridge, 1986), vol. 1, Porfirians, Liberals and Peasants, 15-36.

11 The Mexican Financier, 18 July 1892, as quoted in Cosio Villegas, ed., Historia Moderna, vol. 9, El Porfiriato. la vida political interjor. pt. 2, 324.

12These three attorneys were members of the famous cientificos. "The most lucrative law practices were in their hands," Cosio Villegas writes of the cientificos, "and no one was able to equal them as promoters of national and foreign businesses." Cosio Villegas, ed., Historia moderna, vol. 9, pt. 2,752 .

13Ramon Eduardo Ruiz, The Great Rebellion: Mexico, 1905-1924 (New York, 1980), 51; Cosio Villegas, Cosio Villegas, ed., Historia Moderna, vol. 8, El Porfiriato. Ia vida political interior, pt. 1, 396-7; and Paul J. Vanderwood, Disorder and Progress: Bandits, Police and Merican Development (Lincoln, 1981), 112-113, 119-120.

14Carlos Diaz Dufoo, Mérico y los capitales extranjeros(Mexico City, 1918), 242; and P. H. Morgan to secretary of state, no. 86, 24 August 1880, National Archives, Papers of the United States Department of State, Record Group 59, Despatches of United States Ministers to Merico, 18241906 [hereafter cited as NADS U.S. Ministers].

15Marvin D. Bernstein, The Mexican Mining Industry, 18901950: A Study of the Interaction of Politics, Economics, and Technology (Albany, 1964), 52; Knight, The Mexican Revolution, vol. 2 , 
70; and Morgan to secretary of state, no. 26, 7 June 1880; John Weber to William Hunter, no. 71, 28 October 1880, and no. 72, 11 December 1880 , NADS U.S. Ministers.

${ }^{16}$ José Yves Limantour, Apuntes sobre mi vida pública /1872191//(Mexico, 1965), 84; Great Britain, Foreign Office, Diplomatic and Consular Reports: Merico, 1907(London, 1908), 9; Robert W. Randall, "Mexico's Pre-Revolutionary Reckoning with Railroads," The Americas, 42:1 (July 1985), 26-7; and John H. Coatsworth, Growth Against Development: The Economic Impact of Railroads in Porfirian Mexico(DeKalb. 1981), 45-46.

17Merrill Rippy, Oil and the Mexican Revolution (Leiden, 1972), 726; Antonio J. Bermúdez, The Merican National Petroleum Industry: a Case Study in Nationalization (Stanford, 1963), 2-3; and Bernstein, The Mexican Mining Industry, 11, 18-9, 27-8.

${ }^{18}$ Ezequiel Ordóñez, "El petróleo en Mérico: bosquejo histórico," Revista Mexicano de Ingenieria y Arquetectura, 10:3 (March 1932), 158. For details of the Doheny's interview with Diaz, see United States Congress, Senate, Committee on Foreign Relations Ihereafter cited as Senate Committee on Foreign Relations], Investigation of Mexican Afrairs, 66th Cong., 1st sess., 1919, vol. 1, 212, 218-9, 225.

${ }^{19 C l i f t o n ~ B . ~ K r o e b e r, ~ M a n, ~ L a n d, ~ a n d ~ W a t e r: ~ M e x i c o ~ s ~ F a r m / a n d s ~}$ Irrigation Policies, 1885-191/(Berkeley and Los Angeles, 1983), 8, 219.

${ }^{20}$ The following information comes from J. A. Spender, Weetman Pearson: First Viscount Cowdray, 1856-1927(London, 1930 IReprint, New York, 1977]); and Desmond Young, Member for Mexico: A Biography of Weetman Pearson, First Viscount Cowdray(London, 1966); and Robert Keith Middlemas, The Master Builders: Thomas 
Brassey; Sir John Aird; Lord Cowdray; Sir John Norton-Griffiths (London, 1963).

21 Ibid., 171-2, 175, 180; and President Diaz's message to congress, Diario Oricial, 28 February 1889 in Reinsen Whitehouse to secretary of state, no. 268, 28 February 1889, NASD, U.S. Ministers. Spender, Weetman Pearson, 286-90, lists the company's contracts from 1854 to 1926.

22 Middlemas, The Master Builders, p. 183.

23Ryan to secretary of state, no. 239,7 February 1890 , and no. 253,4 March 1890, NADS, U.S. Ministers.

24"Memorandum by Lord Cowdry, 10 May 1915, British Science Museum Library, London, Records of S. Pearson and Sons Ihereafter cited as Pearson Records], Box A-3; and Cosio Villegas, ed., Historia moderna, vol. 5 , pt. 2, 971.

${ }^{25}$ Clayton to secretary of state, no. 1532, 18 August 1902, and no.

1634, 26 November 1902, NADS, U.S. Ministers.

26 The Mexican Daily Record, 14 May 1906, in D. E. Thompson to secretary of state, no. 69, 25 May 1906, NADS, U.S. Ministers.

${ }^{27}$ As quoted in Young, Member for Mexico, 107-8. On the Tehuantepec railway, see Middlemas, The Master Builders, 194-9.

${ }^{28}$ As quoted in Spender, Weetman Pearson, 149-50.

${ }^{29}$ Body to Pearson, 29 May 1903, 23 June 1905, and Pearson, "Memo for Mr. J. B. Body," 28 April 1908, Pearson Records, Bor A-4.

30Body to Pearson, 23 August 1904, and Pearson to Body, London, 26 Jan 1906, Pearson Records, Box A-4.

31Body to Pearson, Salina Cruz, 29 May 1905, Pearson Records, Box A4. 
1977), 321-326; Joseph A. Pratt, The Growth of a Refining Region

(Greenwich, Conn., 1980), 34-35; and Martin V. Melosi, Coping with

Abundance: Energy and Environment in Industrial America

(Philadelphia, 1985), 40-46.

${ }^{46}$ Senate Committee on Foreign Relations, Investigation of Merican Afrairs, 214-216.

${ }^{47}$ Alfred D. Chandler, Jr., "Technological and Organization

Underpinnings of Modern Industrial Enterprise: The Dynamics of Competitive Advantage," in Multinational Enterprise, 52.

48percy Norman Furber, I Took Chances: From Windjammers to Jels (Leicester, 1953), 141-142, 145.

${ }^{49}$ Guiller mo Landa y Escandón to Pearson, 8 June 1910, Pearson Records, Bor A-4.

${ }^{50}$ See correspondence of A. J. Lespinasse to David E. Thompson, Turpan, 2 October 1908 to 6 October 1908, no.1854, National Archives, Washington, D. C., Records of the Department of State, Diplomatic Despatches from Mexico, 1906-1910 [hereafter cited as NADS, Despatches from Mexicol. 51Body, "Notes for Sir Weetman," 15 May 1909, and Pearson, "Memo for Mr. Body," 9 March 1909, Pearson Reords, Bor A-4. On the relationship between the oilmen and the caudillo Peláez, see Esperanza Duran de Seade, "Mexico's Relations with the Powers During the Great War," D. Phil. Thesis, St. Antony's College, Oxford University, 1980, 283-301.

32Merrill Griffith to assistant secretary of state, Tampico, 15 August 1908, no. 14453/2, NADS, Despatches from Merico.

53 Ibid., 6 July 1908, no. 14453, NADS, Despatches from Mexico; also see The Pipe Line, 3:63 (23 May 1923): 126. 
54Pearson to Henry Clay Pierce, 30 Nov 1907, Pearson Records, Box C44, File 7.

55"Aguila/W aters-Pierce Oil Co. Agreement," 15 May 1908, Pearson Records, Bor C-44, File 7.

56L. to G.W. [sic], 16 May 1908, Pearson Records, Box C-44, File 7.

57pearson to Body, 23 December 1907; Lord Cowdray, "History of the Fight with the Waters Pierce Oil Co." August 1928; and Cowdray, "Private Memo re. negotiations with Mr. Clay Pierce", 8 Mar 1909, Pearson Records, Bor C-44, File 7.

58"Memo to Mr. W. re Agreement with C. P." 30 Jan 1908, L. to H.C.P, 8 February, 1908, C. to H. J., 20 October 1909, and L. to Japp, 8 November 1909, Pearson Records, Box C-44, File 7.

59From private Cowdray papers, as quoted in Middlemas, The Master Builders, 216.

60Ronald MacLeay to Sir Edmund Gray, 18 June 1909, Public Record Office, London, Foreign Office Records (hereafter cited as FO) 368-309, no. 25272.

61 Diario Oricial, 4 February 1904 and 1 April 1904, in Clayton to secretary of state, no. 2235, 11 April 1904, NADS, Despatches from U.S. Ministers.

62Pearson to Dr. M., 16 April 1909, "Summary of Correspondence: Negotiations with W. P. O. Co.," Pearson Records, Bor C-44, File 7.

${ }^{63}$ As quoted in F. C. Gerretson, History of the Royal Dutch, 4 vols. (Leiden, 1953), 4: 261.

640rdónez, "El Petróleo en Mérico," (March 1932) 158.

65 Revolutions in Mexica, 263-265. 
1977), 321-326; Joseph A. Pratt, The Growth of a Refining Region

(Greenwich, Conn., 1980), 34-35; and Martin V. Melosi, Coping with

Abundance: Energy and Environment in Industrial America

(Philadelphia, 1985), 40-46.

46Senate Committee on Foreign Relations, Investigation of Merican Afrairs, 214-216.

${ }^{47}$ Alfred D. Chandler, Jr., "Tecnnological and Organization

Underpinnings of Modern Industrial Enterprise: The Dynamics of Competitive Advantage," in Multinational Enterprise, 52.

48Percy Norman Furber, I Took Chances: From Windjammers to Je1s(Leicester, 1953), 141-142, 145.

${ }^{49}$ Guiller mo Landa y Escandón to Pearson, 8 June 1910, Pearson

Records, Box A-4.

50See correspondence of A. J. Lespinasse to David E. Thompson,

Tuxpan, 2 October 1908 to 6 October 1908, no.1854, National Archives,

Washington, D. C., Records of the Department of State, Diplomatic Despatches

from Merico, 1906-1910 inereafter cited as NADS, Despatches from Mericol.

31Body, "Notes for Sir Weetman," 15 May 1909, and Pearson, "Memo

for Mr. Body," 9 March 1909, Pearson Reords, Bor A-4. On the relationship between the oilmen and the caudillo Pelaez, see Esperanza Durán de Seade, "Mexico's Relations with the Powers During the Great War," D. Phil. Thesis, St. Antony's College, Oxford University, 1980, 283-301.

52Merrill Griffith to assistant secretary of state, Tampico, 15 August 1908 , no. 14453/2, NADS, Despatches from Merico.

53 Ibid., 6 July 1908, no. 14453, NADS, Despatches from Merico; also see The Pipe Line, 3:63 (23 May 1923): 126. 
54Pearson to Henry Clay Pierce, 30 Nov 1907, Pearson Records, Box C44, File 7.

55"Aguila/Waters-Pierce Oil Co. Agreement," 15 May 1908, Pearson Records, Bor C-44, File 7.

36L. to G.W. [sic], 16 May 1908, Pearson Records, Box C-44, File 7.

57pearson to Body, 23 December 1907; Lord Cowdray, "History of the Fight with the Waters Pierce Oil Co." August 1928; and Cowdray, "Private Memo re. negotiations with Mr. Clay Pierce", 8 Mar 1909, Pearson Records, Bor C-44, File 7.

58"Memo to Mr. W. re Agreement with C. P." 30 Jan 1908, L. to H.C.P, 8 February, 1908, C. to H. J., 20 October 1909, and L. to Japp, 8 November 1909, Pearson Records, Boy C-44, File 7.

59From private Cowdray papers, as quoted in Middlemas, The Master Builders, 216.

60Ronald MacLeay to Sir Edmund Gray, 18 June 1909, Public Record Office, London, Foreign Office Records [hereafter cited as F0) 368-309, no. 25272.

61 Diario Oricial, 4 February 1904 and 1 April 1904, in Clayton to secretary of state, no. 2235, 11 April 1904, NADS, Despatches from U.S. Ministers.

62Pearson to Dr. M., 16 April 1909, "Summary of Correspondence: Negotiations with W. P. 0. Co.," Pearson Records, Bor C-44, File 7.

63As quoted in F. C. Gerretson, History of the Royal Dutch, 4 vols. (Leiden, 1953), 4: 261.

640rdónez, "El Petroleo en Mérico," (March 1932) 158.

65 Revolutions in Mexico, 263-265. 
66"Benjamin Ridgely, "A Great Oil Fight in Mexico," 18 July 1908, no. 11770/2-3, Despatches from Merico.

67"Extract from Letter to Senor [sic] Guiller mo Landa," 30 July 1909, Pearson Records, Bor A-4.

68 The Mexican Hers/d, 23 and 29 October 1908.

69See contracts dated 26 November 1908, Pearson Records, Bor C-43, File 2; and document dated 18 October 1908, Archivo General de la Nación, Merico City, Secretaria de Comunicaciones y Obras Públicas, caja 82/118-1. Also see George Philip, Oil and Poljtics in Latin America: Natjonalist Movements and State Companies (Cambridge, 1982), 13-15.

70 The Mexican Herald, 3 November 1908, in no.11770/13-15, NADS, Despatches from Merico.

71"Extract from letter to Senor [sic] Guillermo Landa," 30 July 1909, Pearson Records, Box A-4.

72 /bid.

73Lon Tinkle, Mr. De: A Biography of Everette Lee DeGolyer (Boston, 1970), 15.

74For a detailed description of the scene at Potrero, see ibid., chapter 3; and A. E. Chambers, "Potrero No. 4: A History of One of Mexico's Earliest and Largest Wells," Journal of the Instirution of Petroleum Technologists, 37:9 (1923), 141-164.

75 oif Week/y, 59:11 (28 Nov 1930), 26; and the comments of Robert Stirling in Chambers, "Potrero No. 4,"163-164.

76Spender, Weetman Pearson, 157-158.

77Body to Cowdray, 28 June 1911, Pearson Records, Bor A-4.

78Young, Member for Mexica, 131. 
${ }^{79}$ Ezequiel Ordónez, "El petróleo en México: bosquejo histórico lparte segunda)" Revista Mexicano de Ingenieria y Arquetectura, 10:4 (15 April 1932), 193; Pan American Petroleum Corporation, Mexico Petroleum (New York, 1922), 31-2; and Senate Committee on Foreign Relations, Investigation of Mexican Afrairs, 1: 230-232, 242.

${ }^{80}$ President's message to Congress, Diario Oficial, 26 Febraury 1889, in Reinson Whitehouse to secretary of state, no. 168, 28 Febraury 1889, U.S. Ministers.

${ }^{81}$ Charles C. Eberhardt to Robert Bacon, no. 221, 23 December 1905, NADS, Despatches from U.S. Consuls in Merico City, Merico, 1822-1906; and Durán, "Merico's Relations with the Powers," 13; Philip C. Hanna to Robert Bacon, no. 281, 25 July 1906, NADS, Despatches from U.S. Consuls in Monterrey, Mexico, 1849-1906.

82For recent analysis on the overthrow of Diaz, see Knight, The Mexican Revolution, vol. 1, chapters 2, 3; Friedrich Katz, The Secret War in Mexico: Europe, The Uniled States and the Mexican Revolution (Chicago, 1981), chapter 1; and Michael C. Meyer and William L. Sherman, The Course of Mexican Hislory, 2nd ed. (New York and Oxford, 1983), chapter 31 .

83See Lorenzo Meyer, Mexico and the United Stales in the OiJ Controversy, 1917-1942(Austin, 1977); Jonathan C. Brown, "Why the Foreign Oil Companies Shifted Their Production from Mexico to Venezuela," American Historical Review, 90:2 (Apr. 1985), 362-385; and Wendell C. Gordon, The Expropriation of Foreign-Owned Property in Mexico (Westport, 1975 [Reprint of 1941 edition]). 
TABLE: PRODUCTION OF CRUDE OIL IN MEXICO, 1901-1913, in 42-gallon barrels

Year. Production

1901

1902

1903

1904

1905

1906

1907

1908

1909

1910

1911

1912

1913
10,345

40,200

75.375

125,625

251,250

502,500

$1,005,000$

$3,932,000$

$2,713,500$

$3,634,080$

$12,552,788$

$16,558,215$

$25,696,291$

Source: Charles A. Bay, "Review of the Petroleum Industry in Tampico, 1924," 5 Feb 1925, National Archives, Papers of the Department of State, Record Group 59, Decimal File 812, Mexico, 1910-1929, 812.6363/1558. 